\title{
Bermain Playdough dalam Meningkatkan Kecerdasan Visual-Spasial Melalui Home Visit di Tengah Pandemi Covid-19
}

\begin{abstract}
Niken Widiastita ${ }^{1}$, Laode Anhusadar ${ }^{2}$
1,2 Pendidikan Islam Anak Usia Dini, IAIN Kendari e-mail : niken.widiastita10@gmail.com ${ }^{1}$, sadar.wanchines@gmail.com ${ }^{2}$

ABSTRAK. Penelitian tindakan ini bertujuan untuk meningkatkan kecerdasan visual-spasial melalui kegiatan bermain menggunakan media playdough pada anak kelompok B PAUD Baitul Qur'an Kecamatan Ranomeeto. Dengan subjek penelitian yaitu anak usia 5-6 tahun. Teknik pengumpulan data yang digunakan adalah observasi, dokumentasi, dan hasil karya. Pengumpulan data menggunakan lembar observasi dan portofolio. Proses penelitian dilakukan dalam dua siklus dengan empat tahapan yakni: perencanaan, pelaksanaan, observasi, dan refleksi. Hasil penelitian menunjukan bahwa bermain menggunakan media playdough dapat meningkatkan kecerdasan visual-spasial anak kelompok B PAUD Baitul Qur'an Kecamatan Ranomeeto. Pada siklus satu menunjukkan bahwa perkembangan kecerdasan visual-spasial anak dominan berada pada penilaian mulai berkembang dan berkembang sesuai harapan dengan kriteria ketuntasan 40\% atau berada pada kategori cukup. Pada siklus dua menunjukkan bahwa perkembangan kecerdasan visual-spasial anak dominan berada pada penilaian berkembang sangat baik dengan kriteria ketuntasan sangat baik perkembangan kecerdasan visual-spasial melalui kegiatan bermain playdough pada indikator koordinator mata dan motorik anak dalam membuat berbagai bentuk sebanyak 80\%, kemantapan persepsi anak dalam mengenal macam-macam warna dan ragam bentuk yaitu 90\%, diskriminasi visual anak dalam membedakan dan mengklasifikasikan bentuk dan ukuran suatu benda sebanyak $80 \%$.
\end{abstract}

Kata Kunci : Anak Usia Dini, Kecerdasan Visual-Spasial, Playdough.

ABSTRACT. This aims to improve children's visual-spatial intelligence through playing activities using playdough in the children of the group B PAUD Baitul Qur'an Ranomeeto. Research subject children aged 5-6 years. Data collection techniques used are observation, documentation, and craft results. Data collection using the observation sheet and portfolio. The research process was carried out in two cycle with four stages, namely: planning, implementing, observing, and reflecting. The results showed that playing using playdough could improve visualspatial intelligence of group B PAUD Baitul Qur'an Ranomeeto. Cycle I, it shows that the development of visual-spatial intelligence of children is dominant in the assessment of starting to develop and develop according to expectations with $40 \%$ completeness criteria or in the sufficient category. Cycle II, it shows that the development of visual-spatial intelligence of dominant children is in very well developed assessment with excellent completeness criteria, the development of visual-spatial intelligence through playing playdough activities on the indicators of children's eye and motor coordination in making various forms as much as 80\%, stability of children's perceptions in recognizing the various colors and forms, namely 90\%, the visual discrimination of children in distinguishing and classifying the shape and size of an object is $80 \%$.

Keyword : Early Childhood, Visual-Spatial Intelligence, Playdough 


\section{PENDAHULUAN}

Pada awal Maret 2020 lalu kasus pertama Coronavirus Disease 2019 (Covid-19) di Indonesia diumumkan secara langsung oleh Predisen Joko Widodo. Yang pada akhirnya Indonesia kini tengah dihadapkan pada masa pandemi, hal ini sangat mempengaruhi semua aktivitas kehidupan tak terkecuali pada bidang pendidikan. Dengan diterapkannya kebijakan social distancing atau pembatasan interaksi sosial membuat sekolah-sekolah diliburkan untuk meminimalisir terjadinya interaksi yang menjadi salah satu penyebab penyebaran covid-19. Menurut Sevima penyebaran virus corona ini pada awalnya sangat berdampak pada dunia ekonomi yang mulai lesu, tetapi kini dampaknya dirasakan juga oleh dunia pendidikan. Kebijakan yang diambil oleh banyak negara termasuk Indonesia dengan meliburkan seluruh aktivitas pendidikan, membuat pemerintah dan lembaga terkait harus menghadirkan alternatif proses pendidikan bagi peserta didik maupun mahasiswa yang tidak bisa melaksanakan proses pendidikan pada lembaga pendidikan. Kebijakan di bidang pendidikan yang diambil oleh pemerintah terkait kasus COVID 19 yaitu : pembelajaran daring untuk anak sekolah, kuliah daring, ujian nasional 2020 ditiadakan, UTBK SBMPTN 2020 diundur, dan pelaksanaan SNMPTN masih dalam pengkajian[1].

Pola pembelajaran anak usia dini di satuan-satuan PAUD yang sebelumnya dilakukan dengan pelibatan aktif dari pendidik dan peserta didik melalui kegiatan bermain sambil belajar karena adanya coronavirus disease atau covid-19, semua aktivitas itu di rumahkan. Hewi mengungkapkan bahwa guru PAUD di sekolah melakukan dua tugas pokok sebagai guru yaitu perencana dan penilai hasil perkembangan anak usia dini sementara pendidik PAUD di rumah (orang tua) berfungsi sebagai pelaksana pembelajaran dengan memanfaatkan strategi diskusi (percapakan/tanya jawab) dan keteladanan yaitu anak diajak untuk memahami mengapa sekolah di rumah, mengapa keluar rumah harus menggunakan masker, kenapa tidak bisa bermain di luar rumah. penggunaan strategi ini membuat anak mampu memahami semua hal itu dan mampu membuat tepukan dan lagu tentang covid-19[2]. Proses pembelajaran pada masa pendemi ini diharapkan tetap efektif mengembangkan potensi peserta didik, sehingga guru bisa kreatif dalam proses pembelajaran. Namun pada pelaksanaannya masih banyak pendidik PAUD yang belum mahir menggunakan aplikasi pembelajaran online. Metode pembelajaran yang digunakan masih dominan pemberian tugas kepada peserta didik. Banyak pendidik PAUD yang tidak setuju dengan pembelajaran online karena tidak efektif dan tidak semua orang tua yang memiliki leptop atau HP untuk pembelajaran online[3]. Sehingga dibutuhkan kerjasama guru dan orangtua dalam proses pembelajaran. Menurut Maryani, perlunya kerjasama dengan pihak orang tua dengan melakukan komunikasi efektif berkaitan dengan kegiatan pembelajaran yang dilakaukan selama pembelajaran dari rumah karena pelaksana kegiatan adalah orang tua. Berikan penjelasan mengenai pentingnya memberikan stimulasi sejak dini dan melakukan laporan kegiatan anak kepada guru melalui artikelartikel ataupun melalui komunikasi langsung. Kegiatan dapat berupa perencanaan yang telah dirancang dari lembaga ataupun kegiatan yang dilakukan bersama orang tua di rumah[4].

Penelitian ini dilakukan dengan program home visit atau kunjungan kerumah anak, tentunya program ini dilakukan pada wilayah zona hijau di provinsi Sulawesi Tenggara tepatnya pada Kecamatan Ranomeeto Kabupaten Konawe Selatan. Home visit dalam praktiknya bertujuan untuk memberikan stimulasi melalui ragam aktivitas bermain yang dilakukan dengan kunjungan kerumah anak[5]. Pembelajaran tatap muka yang berada di wilayah zona hijau diharuskan mengikuti protokol kesehatan dengan 
membudayakan pola hidup bersih dan sehat dalam rangka pencegahan penyebaran covid-19 sesuai dengan panduan penyelenggaraan pembelajaran pada tahun ajaran 2020/2021 dan tahun akademik 2020/2021 di masa pandemi coronavirus disease 2019 (covid-19) yang diterbitkan oleh Menteri Pendidikan dan Kebudayaan, Menteri Agama, Menteri Kesehatan, dan Menteri Dalam Negeri.

Lembaga pendidikan anak usia dini (PAUD) merupakan lembaga yang di peruntukan bagi anak pada masa usia prasekolah untuk membantu anak dalam mengembangkan seluruh potensi yang dimilikinya agar dapat terstimulasi dengan optimal yang lebih lanjut dijelaskan dalam Undang-Undang No. 20 Tahun 2003 tentang Sistem Pendidikan Nasional bahwa lembaga pendidikan anak usia dini (PAUD) merupakan suatu upaya pembinaan dan pemberian stimulasi perkembangan yang diperuntukan kepada anak sejak lahir sampai usia 6 tahun agar anak memiliki kesiapan dalam memasuki jenjang pendidikan selanjutnya. Salah satu upaya dalam mengembangkan potensi anak melalui lembaga PAUD yaitu merancang kegiatan main sebagai model kegiatan pembelajaran anak yang dilakukan secara menyenangkan[6]. Dengan harapan seluruh potensi anak dapat berkembang secara optimal melalui pemberian rangsangan pendidikan tersebut. Anak usia dini sering disebut sebagai masa dimana anak mengalami pertumbuhan dan perkembangan yang sangat pesat dalam berbagai aspek perkembangannya, yang meliputi 6 aspek perkembangan anak yaitu, nilai agama dan moral, sosial emosional, bahasa, kognitif, fisik motorik, dan seni. Pada tahap inilah, merupakan masa yang tepat untuk menanamkan nilai-nilai kebaikan yang nantinya diharapkan dapat membentuk keperibadiannya. Dari ke 6 aspek perkembangan anak itu mencakup kecerdasan majemuk (multiple intelligence).

Teori Multiple Intelligence ditemukan dan dikembangkan oleh Howard Gardner menjadi solusi yang adil dan tepat, bahwa melihat anak sebagai individu yang unik dan cerdas. Dari aspek perkembangan anak dan kecerdasan majemuk terdapat keterkaitan yang sangat erat antara satu dan yang lainnya, dibuktikan bahwa kecerdasan visualspasial mencakup dari aspek perkembangan kognitif dan fisik motorik terutama aspek motorik halus anak, karena dalam berbagai kegiatan yang menggunakan kecerdasan visual-spasial akan meningkatkan perkembangan kognitif dan perkembangan motorik halus anak. Kecerdasan visual-spasial merupakan kemampuan seseorang berpikir dalam ruang tiga dimensi. Menurut Gardner, kecerdasan visual-spasial berkaitan dengan keterampilan dan persepsi dalam bidang permainan warna, bentuk, ruang, dan garis[7]. Sedangkan menurut Rosidah, kecerdasan visual-spasial merupakan kemampuan seseorang membentuk suatu model dalam pikirannya tentang spasial dan kemampuan menggunakan model tersebut di dunia nyata[8]. Kecerdasan visual-spasial dapat dikembangkan melalui kegiatan membayangkan, menggambar, membuat kerajinan, mengatur, dan merancang, membentuk dan bermain konstruktif, bermain sandiwara boneka, meniru gambar objek, bermain dengan lilin mainan atau playdough, menyusun objek mainan, bermain peran, membaca buku, dan bermain video game[9]. Kegiatan tersebut merupakan kegiatan yang melibatkan semua indera anak dalam pembelajaran yang diawali dengan menampilkan model dan diakhiri dengan membuat atau menciptakan sesuatu. Sehingga prestasi dalam kecerdasan majemuk bukan hanya prestasi dalam bidang akademik. Kecerdasan majemuk memungkinkan anak untuk memiliki peluang yang sangat besar dalam meraih kesuksesan, jika kecerdasan majemuk tersebut dilatih secara terus menerus.

Kegiatan bermain merupakan metode yang tepat digunakan dalam lembaga PAUD untuk menstimulasi perkembangan anak dengan melakukan kegiatan yang serius namun tetap menyenangkan dan menghibur bagi anak[10]. Salah satu kegiatan bermain 
yang dapat meningkatkan kecerdasan visual-spasial anak dengan membentuk sesuatu menggunakan playdough[11]. Menurut Jatmika, playdough adalah adonan mainan yang merupakan bentuk modern dari tanah liat atau lempung yang terbuat dari campuran terigu[12]. Bermain menggunakan media playdough dapat memberikan kesenangan pada anak terutama ketika anak meremas, menggulung, memilin, membentuk dan menciptakan kombinasi yang baru dengan melalui media playdough. Anak terlatih untuk terus menerus menggunakan daya imajinasinya untuk membuat bentuk-bentuk yang baru dan unik. Media bermain ini merupakan media yang elastis sehingga mudah bagi anak untuk membentuk suatu pola serta memiliki aneka ragam warna yang dapat menstimulasi imajinasi anak untuk berkreasi dengan menggunakan playdough.

PAUD Baitul Qur'an Kecamatan Ranomeeto Kabupaten sebagai salah satu satuan PAUD yang memberikan layanan pada anak usia 4-6 tahun. Berdasarkan fakta lapangan yang ditemukan maka peneliti tertarik untuk melakukan kajian tentang bermain menggunakan media playdough untuk kecerdasan visual-spasial anak. Hal ini didukung oleh temuan penelitian yang telah ada mengenai permainan untuk menstimulasi perkembangan anak usia dini, peneliti memiliki keyakinan bahwa bermain melalui media playdough dapat mengembangkan kecerdasan visual-spasial anak usia 5-6 tahun di PAUD Baitul Qur'an Kecamatan Ranomeeto Kabupaten Konawe Selatan.

\section{METODE}

Penelitian ini menggunakan metode penelitian tindakan (Action Research) yang dikembangkan oleh Kurt Lewin[13]. Yang selanjutnya oleh Stephen Corey dikembangkan dalam bidang pendidikan yang kemudian dikenal dengan sebutan penelitian tidakan kelas (Classroom Action Research). PTK yang dilakukan oleh guru untuk memperbaiki kualitas didalam kelasnya[14]. Penelitian tindakan ini merupakan upaya untuk meningkatan mutu pembelajaran yang dilakukan dengan cara pemberian tindakan tertentu. Penggunaan metode penelitian ini untuk melihat kegiatan belajar di satuan PAUD dengan memberikan tindakan tertentu yang sengaja dilakukan untuk melihat perkembangan kecerdasan visual-spasial anak usia 5-6 tahun yang ada di PAUD Baitul Qur'an Kecamatan Ranomeeto Kabupaten Konawe Selatan. Penelitian akan dilakukan dalam dua siklus yaitu siklus I dan siklus II, yang masing-masing siklus terdiri dari tiga kali pertemuan. Model penelitian tindakan yang dipilih adalah siklus model Kemmis dan Taggart yang memiliki empat tahapan perencanaan, tindakan, observasi dan refleksi[15]. Adapun subjek penelitian ini adalah anak kelompok B PAUD Baitul Qur'an Kecamatan Ranomeeto Kabupaten Konawe Selatan yang berjumlah 10 orang dan terdiri dari 4 anak laki-laki dan 6 anak perempuan yang berada pada rentang usia 5-6 tahun.

Pengumpulan data dalam penelitian ini menggunakan teknik observasi dan dokumentasi pada pelaksanaan pembelajaran dengan menggunakan media playdough. Adapun jenis instrumen yang digunakan dalam penelitian ini yaitu menggunakan teknik observasi, dokumentasi dan penilaian (penilaian performance/perbuatan) pada tindakan pelaksanaan bermain playdough. Analisis data penelitian dilakukan melalui dua cara yaitu teknik analisis kuantitatif deskriptif dan analisis data kualitatif. Analisis kuantitatif deskriptif dilakukan mencari presentase kecerdasan visual-spaisial anak dengan menggunakan rumus yaitu dari Purwanto[16], sebagai berikut: 


$$
P=\frac{f}{N} \times 100 \%
$$

$$
\begin{aligned}
& \text { Keterangan : } \\
& \mathrm{P}=\text { Angka Presentase } \\
& \mathrm{F}=\text { Frekuensi yang dicari Presentasenya } \\
& \mathrm{N}=\text { Jumlah Frekuensi atau Banyaknya Individu }
\end{aligned}
$$

Perkembangan kecerdasan visual-spasial anak ditentukan menggunakan kriteria yang ditetapkan oleh peneliti dengan memodifikasi dan berpedoman pada kriteria ketuntasan belajar dari Sudijono[17] yaitu :

90\%-100\% : kriteria sangat baik perkembangan kecerdasan visual-spasial anak

70\%-89\% : kriteria cukup perkembangan kecerdasan visual-spasial anak

$31 \%-69 \% \quad$ : kriteria kurang baik perkembangan kecerdasan visual-spasial anak

$0 \%-30 \% \quad$ : kriteria tidak baik perkembangan kecerdasan visual-spasial anak

\section{HASIL DAN PEMBAHASAN}

Berdasarkan hasil observasi dan dokumentasi dan penilaian mengenai capaian perkembangan kecerdasan visual-spasial anak kelompok B pada rentang usia 5-6 tahun sebelum pelaksanaan siklus satu atau pra tindakan di PAUD Baitul Qur'an Kecamatan Ranomeeto Kabupaten Konawe Selatan yaitu sebagai berikut: Berdasarkan data pra tindakan perkembangan kecerdasan visual-spasial anak dalam tabel 1 maka diperoleh informasi bahwa pada indikator koordinator mata dan motorik anak dalam membuat berbagai bentuk sebanyak $30 \%$ atau 3 orang anak berada pada rentang penilaian belum berkembang, $50 \%$ atau 5 orang anak berada pada rentang penilaian mulai berkembang dan $20 \%$ atau 2 orang anak pada rentang penilaian berkembang sesuai harapan. Selanjutnya indikator yang kedua yaitu kemantapan persepsi anak dalam mengenal macam-macam warna dan ragam bentuk sebanyak $30 \%$ atau 3 orang anak berada pada rentang penilaian belum berkembang, $40 \%$ atau 4 orang anak berada pada rentang penilaian mulai berkembang, $20 \%$ atau 2 orang anak berada pada rentang penilaian berkembang sesuai harapan, dan $10 \%$ atau 1 orang anak berada pada tentang penilaian berkembang sangat baik. Pada indikator terakhir yang diamati yaitu diskriminasi visual anak dalam membedakan bentuk hasil karya serta dapat membedakan ukuran suatu benda sebanyak $40 \%$ atau 4 anak berada rentang penilaian belum berkembang, 50\% atau 5 orang anak berada pada rentang penilaian mulai berkembang, dan $10 \%$ atau 1 orang anak berada pada rentang penilaian berkembang sesuai harapan.
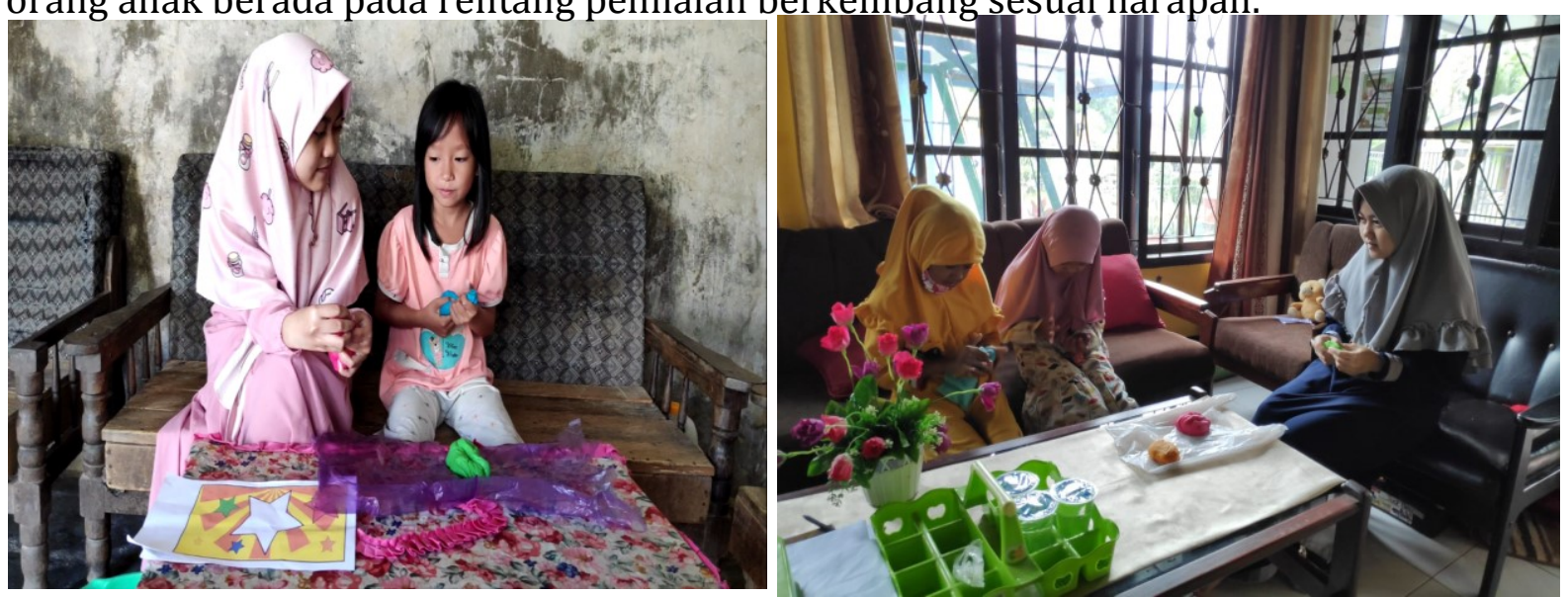

Gambar. 1 Proses Pelaksanaan Pembelajaran Home visit

Data perkembangan kecerdasan visual-spasial anak yang diperoleh dari hasil pra tindakan, selanjutnya ditindaklanjuti oleh peneliti dengan menyusun perencanaan untuk 
melaksanakan tindakan penggunaan media playdough untuk meningkatkan kecerdasan visual-spasial anak usia 5-6 tahun di PAUD Baitul Qur'an Kecamatan Ranomeeto Kabupaten Konawe Selatan. Pelaksanaan tindakan siklus satu dilaksanakan selama 3 kali pertemuan yaitu pada tanggal 30 Maret, 6 April dan 13 April 2020.

Setelah pelaksanaan tindakan pada siklus satu yaitu penggunaan media playdough untuk perkembangan kecerdasan visual-spasial anak usia 5-6 tahun di PAUD Baitul Qur'an Kecamatan Ranomeeto Kabupaten Konawe Selatan. Pada pertemuan pertama dari pelaksanaan tindakan siklus satu yaitu pada indikator koordinasi mata dan motorik anak dalam melakukan kegiatan bermain melalui media playdough sebanyak $20 \%$ atau 2 orang anak berada pada rentang penilaian belum berkembang, $60 \%$ atau 6 orang anak berada pada rentang penilaian mulai berkembang, dan $20 \%$ atau 2 orang anak berada pada rentang penilaian berkembang sesuai harapan. Indikator yang kedua kemantapan persepsi dalam melakukan kegiatan bermain melalui media playdough sebanyak $10 \%$ atau 1 orang anak berada pada rentang perkembangan belum berkembang, $60 \%$ atau 6 orang anak berada pada rentang penilaian mulai berkembang, $20 \%$ atau 2 orang anak berada pada rentang perkembangan berkembang sesuai harapan dan $10 \%$ atau 1 orang anak berada pada rentang penilaian berkembang sangat baik. Dan indikator yang terakhir yaitu indikator diskriminasi visual anak dalam melakukan kegiatan bermain sebanyak $30 \%$ atau 3 orang anak berada pada rentang penilaian belum berkembang, $60 \%$ atau 6 orang anak berada pada rentang penilaian mulai berkembang, dan $10 \%$ atau 1 orang anak berada pada rentang penilaian berkembang sesuai harapan.

Pada pertemuan kedua dari pelaksanaan tindakan siklus satu yaitu pada indikator koordinasi mata dan motorik anak dalam melakukan kegiatan bermain melalui media playdough sebanyak $10 \%$ atau 1 orang anak berada pada rentang penilaian belum berkembang, $60 \%$ atau 6 orang anak berada pada rentang penilaian mulai berkembang, $20 \%$ atau 2 orang anak berada pada rentang penilaian berkembang sesuai harapan, dan $10 \%$ atau 1 orang anak berada pada rentang penilaian berkembang sangat baik. Indikator yang kedua kemantapan persepsi dalam melakukan kegiatan bermain melalui media playdough sebanyak $60 \%$ atau 6 orang anak berada pada rentang penilaian mulai berkembang, 30\% atau 2 orang anak berada pada rentang perkembangan berkembang sesuai harapan dan $10 \%$ atau 1 orang anak berada pada rentang penilaian berkembang sangat baik. Dan indikator yang terakhir yaitu indikator diskriminasi visual anak dalam melakukan kegiatan bermain sebanyak $20 \%$ atau 2 orang anak berada pada rentang penilaian belum berkembang, $70 \%$ atau 7 orang anak berada pada rentang penilaian mulai berkembang, dan $10 \%$ atau 1 orang anak berada pada rentang penilaian berkembang sesuai harapan.

Pada pertemuan ketiga dari pelaksanaan tindakan siklus dua yaitu pada indikator koordinasi mata dan motorik anak dalam melakukan kegiatan bermain melalui media playdough sebanyak $40 \%$ atau 4 orang anak berada pada rentang penilaian mulai berkembang, $40 \%$ atau 4 orang anak berada pada rentang penilaian berkembang sesuai harapan, dan $20 \%$ atau 2 orang anak berada pada rentang penilaian berkembang sangat baik. Indikator yang kedua kemantapan persepsi dalam melakukan kegiatan bermain melalui media playdough sebanyak $30 \%$ atau 3 orang anak berada pada rentang penilaian mulai berkembang, $30 \%$ atau 3 orang anak berada pada rentang perkembangan berkembang sesuai harapan dan $40 \%$ atau 4 orang anak berada pada rentang penilaian berkembang sangat baik. Dan indikator yang terakhir yaitu indikator diskriminasi visual anak dalam melakukan kegiatan bermain sebanyak $10 \%$ atau 1 orang anak berada pada rentang penilaian belum berkembang, $40 \%$ atau 4 orang anak 
berada pada rentang penilaian mulai berkembang, 40\% atau 4 orang anak berada pada rentang penilaian berkembang sesuai harapan, dan $10 \%$ atau 1 orang anak berada pada rentang penilaian berkembang sangat baik.

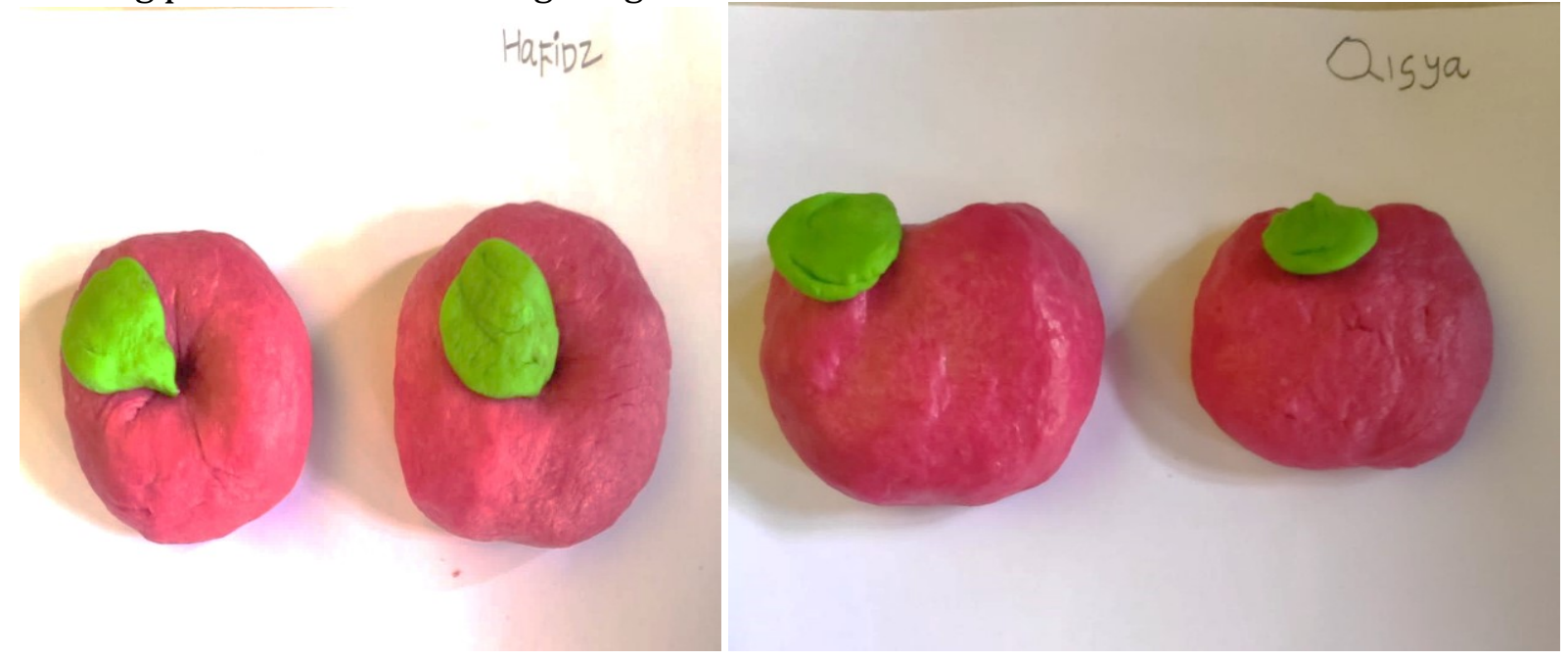

Gambar 2. Hasil Karya Peserta didik pada Siklus 1.

Berdasarkan data yang diperoleh peneliti dari pelaksanaan tindakan siklus satu diperoleh informasi bahwa capaian keseluruhan indikator perkembangan kecerdasan visual-spasial berada pada kategori cukup sehingga peneliti memutuskan untuk meneruskan pemberian tindakan ke siklus kedua.

Pelaksanaan tindakan siklus kedua dilaksanakan selama 3 kali pertemuan yaitu pada bulan Mei tanggal 6,12 dan 25 Mei 2020. Setelah pelaksanaan tindakan pada siklus satu yaitu penggunaan media playdough untuk perkembangan kecerdasan visual-spasial anak usia 5-6 tahun di PAUD Baitul Qur'an Kecamatan Ranomeeto Kabupaten Konawe Selatan diperoleh data sebagai berikut: Pada pertemuan pertama dari pelaksanaan tindakan siklus kedua yaitu pada indikator koordinasi mata dan motorik anak dalam melakukan kegiatan bermain melalui media playdough sebanyak $30 \%$ atau 3 orang anak berada pada rentang penilaian mulai berkembang, 40\% atau 4 orang anak berada pada rentang penilaian berkembang sesuai harapan dan 30\% atau 3 orang anak berada pada rentang penilaian berkembang sangat baik. Indikator yang kedua kemantapan persepsi dalam melakukan kegiatan bermain melalui media playdough sebanyak $50 \%$ atau 5 orang anak berada pada rentang penilaian berkembang sesuai harapan dan $50 \%$ atau 5 orang anak berada pada rentang penilaian berkembang sangat baik. Dan indikator yang terakhir yaitu indikator diskriminasi visual anak dalam melakukan kegiatan bermain sebanyak $40 \%$ atau 4 orang anak berada pada rentang penilaian mulai berkembang, $40 \%$ atau 4 orang anak berada pada rentang penilaian berkembang sesuai harapan, dan $20 \%$ atau 2 orang anak berada pada rentang penilaian berkembang sangat baik.

Pada pertemuan kedua dari pelaksanaan tindakan siklus kedua yaitu pada indikator koordinasi mata dan motorik anak dalam melakukan kegiatan bermain melalui media playdough sebanyak $30 \%$ atau 3 orang anak berada pada rentang penilaian berkembang sesuai harapan dan $70 \%$ atau 7 orang anak berada pada rentang penilaian berkembang sangat baik. Indikator yang kedua kemantapan persepsi dalam melakukan kegiatan bermain melalui media playdough sebanyak $20 \%$ atau 2 orang anak berada pada rentang penilaian berkembang sesuai harapan dan $80 \%$ atau 8 orang anak berada pada rentang penilaian berkembang sangat baik. Dan indikator yang terakhir yaitu indikator diskriminasi visual anak dalam melakukan kegiatan bermain sebanyak 
$10 \%$ atau 1 orang anak berada pada rentang penilaian mulai berkembang, $30 \%$ atau 3 orang anak berada pada rentang penilaian berkembang sesuai harapan, dan $60 \%$ atau 6 orang anak berada pada rentang penilaian berkembang sangat baik.

Pada pertemuan ketiga dari pelaksanaan tindakan siklus kedua yaitu pada indikator koordinasi mata dan motorik anak dalam melakukan kegiatan bermain melalui media playdough sebanyak $20 \%$ atau 2 orang anak berada pada rentang penilaian berkembang sesuai harapan dan $80 \%$ atau 8 orang anak berada pada rentang penilaian berkembang sangat baik. Indikator yang kedua kemantapan persepsi dalam melakukan kegiatan bermain melalui media playdough sebanyak $10 \%$ atau 1 orang anak berada pada rentang penilaian berkembang sesuai harapan dan $90 \%$ atau 9 orang anak berada pada rentang penilaian berkembang sangat baik. Dan indikator yang terakhir yaitu indikator diskriminasi visual anak dalam melakukan kegiatan bermain sebanyak $20 \%$ atau 2 orang anak berada pada rentang penilaian berkembang sesuai harapan, dan $80 \%$ atau 8 orang anak berada pada rentang penilaian berkembang sangat baik.

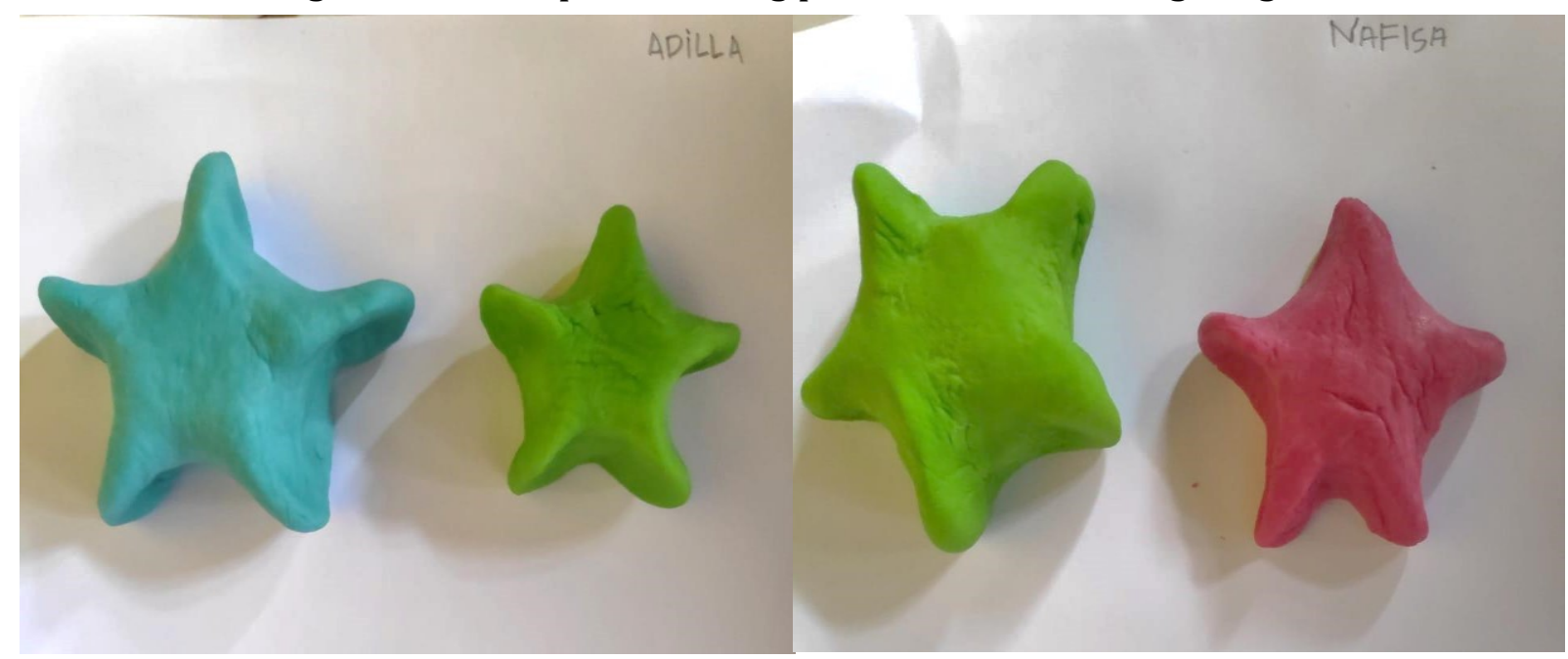

Gambar 3. Hasil Karya Peserta Didik pada Siklus 2.

Perkembangan kecerdasan visual-spasial anak kelompok B usia 5-6 tahun di PAUD Baitul Qur'an Kecamatan Ranomeeto Kabupaten Konawe Selatan dapat diidentifikasi dengan baik dan teratur melalui tampilan grafik kecerdasan visual-spasial anak sebelum dan sesudah diberikan tindakan yaitu melalui bermain playdough untuk meningkatkan kecerdasan visual-spasial anak, sebagai berikut: 


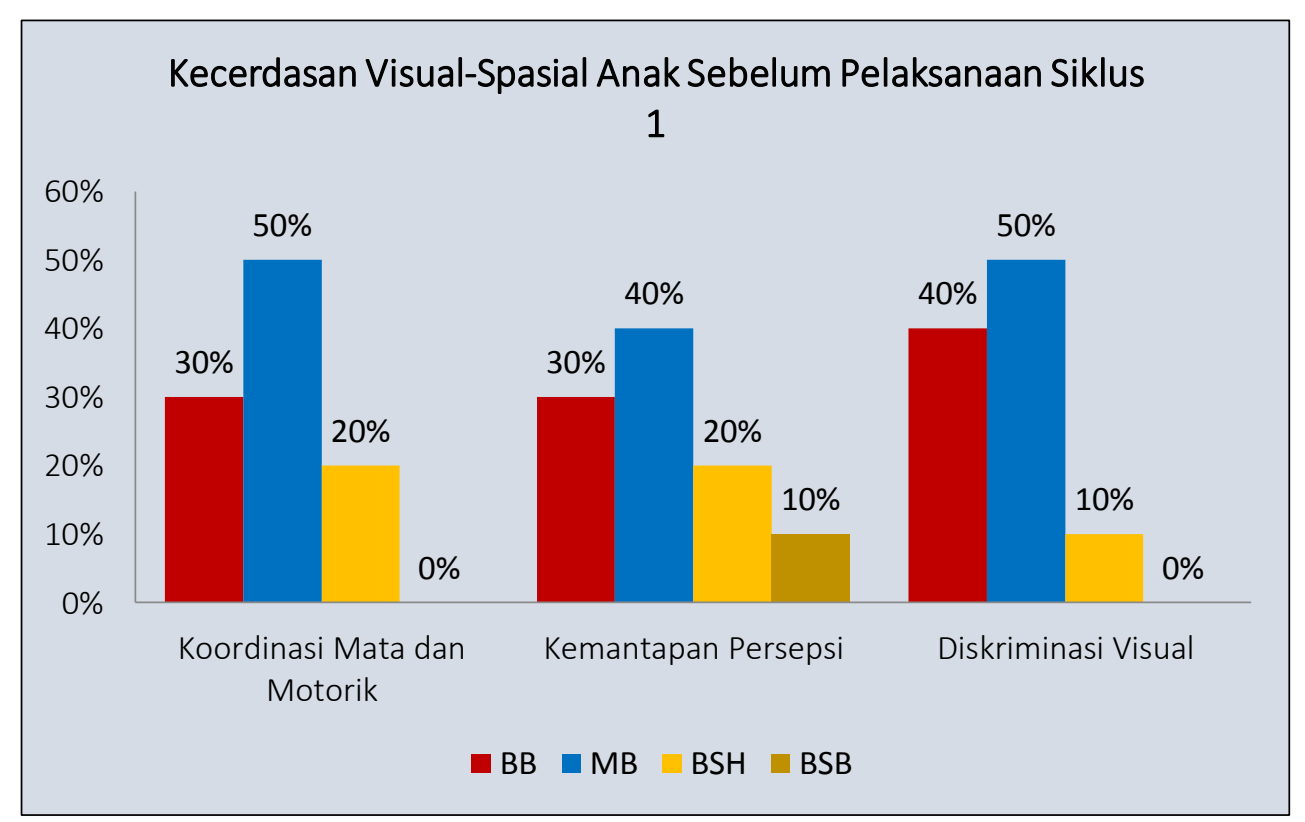

Berdasarkan data yang disajikan dalam bentuk grafik kecerdasan visual-spasial anak sebelum pelaksanaan tindakan siklus satu menunjukkan bahwa pada indikator koordinator mata dan motorik anak dalam membuat berbagai bentuk sebanyak $50 \%$ atau 5 orang anak berada pada rentang penilaian mulai berkembang, 30\% atau 3 orang anak berada pada rentang penilaian belum berkembang dan $20 \%$ atau 2 orang anak pada rentang penilaian berkembang sesuai harapan. Selanjutnya indikator yang kedua yaitu kemantapan persepsi anak dalam mengenal macam-macam warna dan ragam bentuk sebanyak $40 \%$ atau 4 orang anak berada pada rentang penilaian mulai berkembang, $30 \%$ atau 3 orang anak berada pada rentang penilaian belum berkembang, $20 \%$ atau 2 orang anak berada pada rentang penilaian berkembang sesuai harapan, dan $10 \%$ atau 1 orang anak berada pada tentang penilaian berkembang sangat baik. Pada indikator terakhir yang diamati yaitu diskriminasi visual anak dalam membedakan bentuk hasil karya serta dapat membedakan ukuran suatu benda sebanyak $50 \%$ atau 5 anak berada rentang penilaian mulai berkembang, $40 \%$ atau 4 orang anak berada pada rentang penilaian belum berkembang, dan $10 \%$ atau 1 orang anak berada pada rentang penilaian berkembang sesuai harapan. Hasil penilaian kecerdasan visual-spasial anak berdasarkan grafik kecerdasan visual-spasial anak sebelum pelaksanaan siklus satu diperoleh informasi bahwa tiga indikator kecerdasan visual-spasial anak dominan berada pada penilaian mulai berkembang, belum berkembang, berkembang sesuai harapan, dan berkembang sangat baik dengan kriteria ketuntasan perkembangan yaitu cukup dan kurang baik, hal ini berarti bahwa capaian perkembangan anak secara keseluruhan masih dalam kategori sangat rendah perkembangannya. Menurut Difatiguna bahwa ada pengaruh antara aktivitas bermain menggunakan playdough terhadap kemampuan motorik halus anak, dibuktikan dengan adanya peningkatan kemampuan motorik halus pada anak usia 4-5 tahun di TK Dharma Wanita Kecamatan Pesisir Utara Kabupaten Pesisir Barat sebanyak 4-5 capain indikator setiap pertemuan[18].

Selanjutnya pemberian tindakan dilakukan pada siklus satu sebanyak tiga kali pertemuan dengan kegiatan bermain melalui media playdough untuk perkembangan kecerdasan visual-spasial anak yang kemudian dilakukan penilaian untuk melihat capaian perkembangan anak. Adapun capaian perkembangan kecerdasan visual-spasial anak untuk siklus satu yaitu sebagai berikut: 


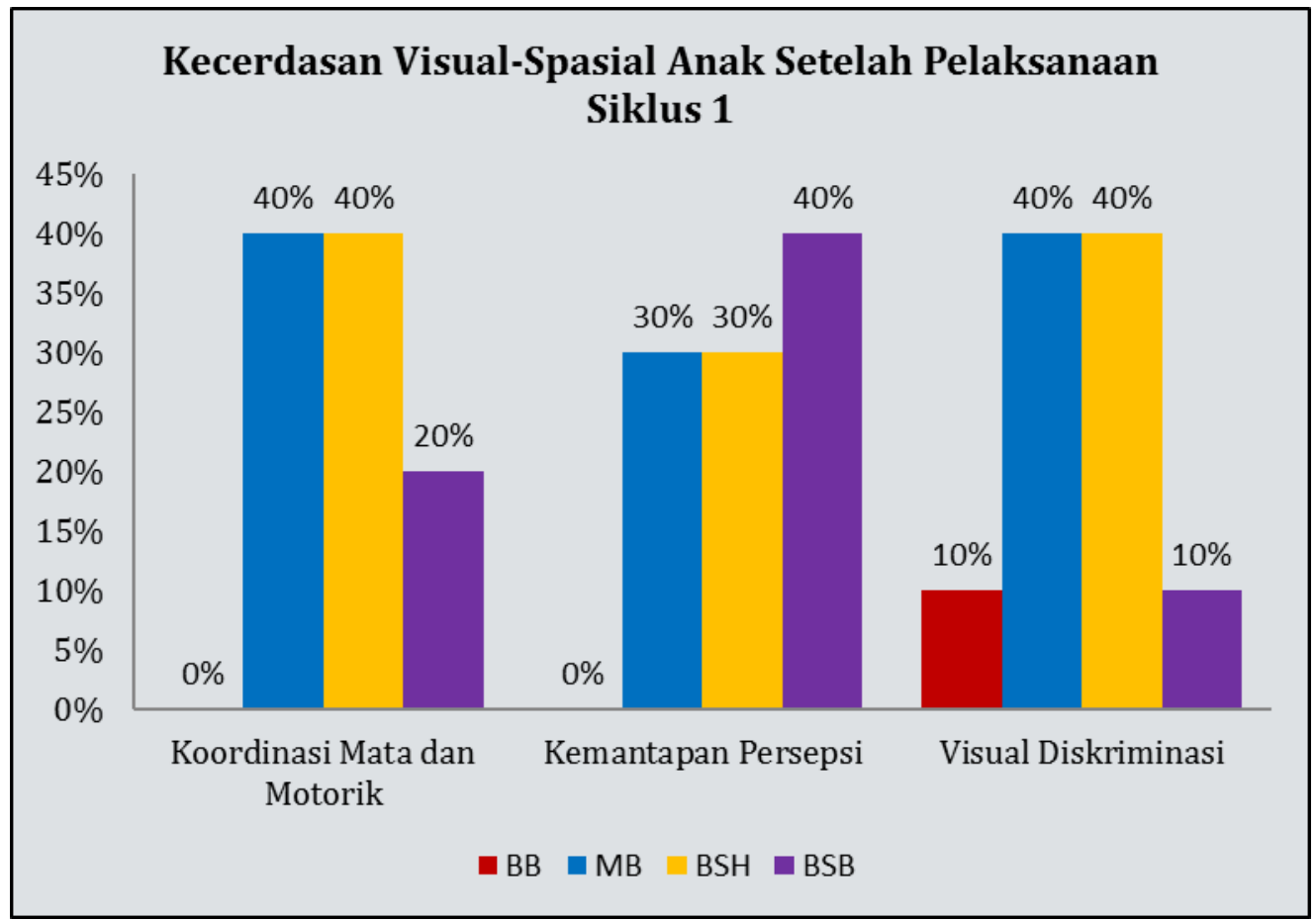

Berdasarkan data yang ditampilkan dalam bentuk grafik diatas capaian kecerdasan visual-spasial anak setelah pelaksanaan tindakan siklus satu menunjukkan bahwa pada indikator koordinator mata dan motorik anak dalam membuat berbagai bentuk sebanyak $40 \%$ atau 4 orang anak berada pada rentang penilaian mulai berkembang, $40 \%$ atau 4 orang anak berada pada rentang penilaian berkembang sesuai harapan dan $20 \%$ atau 2 orang anak pada rentang penilaian berkembang sangat baik. Selanjutnya indikator yang kedua yaitu kemantapan persepsi anak dalam mengenal macam-macam warna dan ragam bentuk sebanyak $40 \%$ atau 4 orang anak berada pada rentang penilaian berkembang sangat baik, $30 \%$ atau 3 orang anak berada pada rentang penilaian berkembang sesuai harapan, dan 30\% atau 3 orang anak berada pada rentang penilaian mulai berkembang. Pada indikator terakhir yang diamati yaitu diskriminasi visual anak dalam membedakan bentuk hasil karya anak serta dapat membedakan ukuran suatu benda sebanyak $40 \%$ atau 4 anak berada rentang penilaian berkembang sesuai harapan, $40 \%$ atau 4 orang anak berada pada rentang penilaian mulai berkembang, $10 \%$ atau 1 orang anak berada pada rentang penilaian belum berkembang, dan $10 \%$ atau 1 orang anak berada pada rentang penilaian berkembang sangat baik. Hasil penilaian kecerdasan visual-spasial anak berdasarkan grafik setelah pelaksanaan siklus satu menunjukkan bahwa tiga aspek indikator perkembangan kecerdasan visualspasial dominan berada pada penilaian mulai berkembang dan berkembang sesuai harapan dengan kriteria ketuntasan perkembangan yaitu cukup hal ini berarti bahwa capaian perkembangan kecerdasan visual-spasial anak secara keseluruhan masih dalam kategori cukup. Oleh sebab itu pemberian tindakan bermain melalui media playdough untuk perkembangan kecerdasan visual-spasial anak dilanjutkan pada siklus kedua. Menurut Suriantoso bahwa permainan playdough dapat meningkatkan kemampuan motorik halus pada peserta didik Kelompok Bermain PAUD Tegaljaya. Hal ini dapat dilihat pada kenaikan persentase ketuntasan yang terjadi pada kondisi awal dari 12 siswa mencapai ketuntasan hanya 4 anak (33,33\%), pada siklus I meningkat menjadi 5 anak (41,67\%) dan pada siklus II meningkat lagi menjadi 10 anak (83,33\%). Kemampuan motorik halus anak yang mengalami peningkatan diantaranya kemampuan meremas, memilin, mencetak, dan membuat bentuk kreasi dengan playdough[19]. 
Berikut data yang ditampilan dalam bentuk grafik terkait perkembangan kecerdasan visual-spasial melalui kegiatan bermain menggunakan media playdough setelah pelaksanaa siklus dua yaitu sebagai:

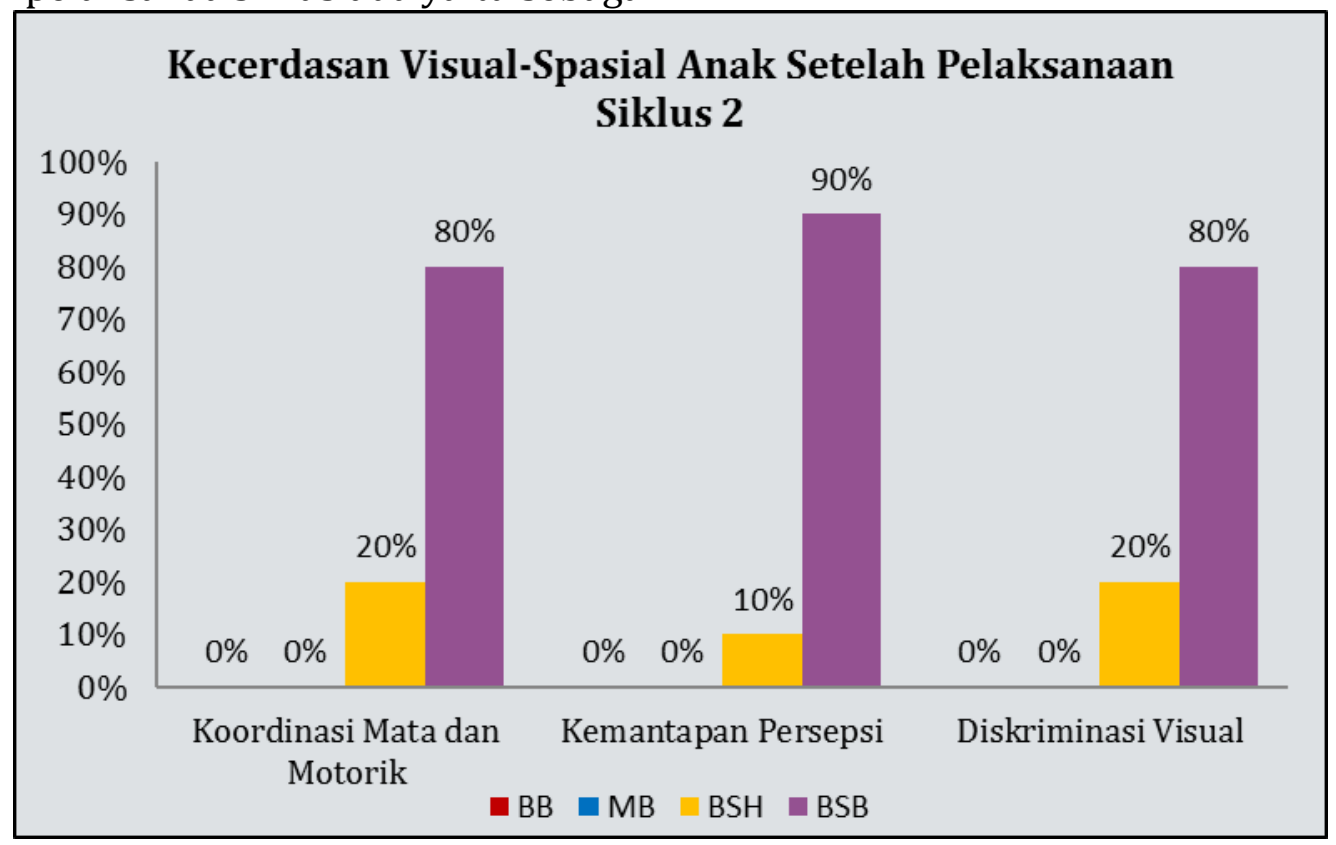

Berdasarkan data yang disajikan dalam bentuk grafik diatas capaian kecerdasan visual-spasial anak setelah pelaksanaan tindakan siklus dua menunjukkan bahwa pada indikator koordinator mata dan motorik anak dalam membuat berbagai bentuk sebanyak $80 \%$ atau 8 orang anak berada pada rentang penilaian berkembang sangat baik dan $20 \%$ atau 2 orang anak pada rentang penilaian berkembang sesuai harapan. Selanjutnya indikator yang kedua yaitu kemantapan persepsi anak dalam mengenal macam-macam warna dan ragam bentuk sebanyak $90 \%$ atau 9 orang anak berada pada rentang penilaian berkembang sangat baik dan 10\% atau 1 orang anak berada pada rentang penilaian berkembang sesuai harapan. Pada indikator terakhir yang diamati yaitu diskriminasi visual anak dalam membedakan berbagi bentuk hasil karya anak serta dapat membedakan ukuran suatu bentuk sebanyak $80 \%$ atau 8 orang anak berada pada rentang penilaian berkembang sangat baik, dan $20 \%$ atau 2 orang anak berada pada rentang penilaian berkembang sesuai harapan. Menurut Elik bahwa hasil pembelajaran sudah mencapai ketuntasan belajar anak dimana tingkat perkembangan anak berada pada tingkat berkembang sangat baik (BSB) dan dinyatakan berhasil. Kesimpulannya bahwa penggunaan permainan playdough dapat meningkatkan kemampuan anak dalam mengenal angka di TK Bahrul Ulun Mopuya[20].

Hasil penilaian kecerdasan visual-spasial anak berdasarkan grafik setelah pelaksanaan siklus kedua menunjukkan bahwa tiga aspek indikator perkembangan kecerdasan visual-spasial berada pada penilaian berkembang sangat baik dengan kriteria ketuntasan perkembangan sangat baik untuk perkembangan kecerdasan visualspasial melalui kegiatan bermain playdough pada indikator koordinator mata dan motorik anak dalam membuat berbagai bentuk sebanyak 80\%, kemantapan persepsi anak dalam mengenal macam-macam warna dan ragam bentuk yaitu 90\%, diskriminasi visual anak dalam membedakan berbagai bentuk hasil karya anak serta dapat membedakan ukuran suatu benda sebanyak $80 \%$. Berdasarkan hasil yang didapatkan setelah pelaksanaan siklus kedua maka pemberian tindakan yaitu penggunaan media playdough untuk meningkatkan kecerdasan visual-spasial anak dihentikan oleh peneliti. 
Berdasarkan temuan penelitian yang telah di uraikan oleh peneliti di atas bahwa penggunaan media playdough untuk menstimulasi perkembangan kecerdasan visual-spasial anak usia 5-6 tahun pada tiga indikator perkembangan yaitu koordinator mata dan motorik, kemantapan persepsi, dan diskriminasi visual memiliki capaian perkembangan pada penilaian yaitu BSB dengan kriteria ketuntasan perkembangan sangat baik. Temuan penelitian ini sesuai dengan temuan peneliti lainnya yang lebih dulu melakukan penelitian tentang media untuk menstimulasi perkembangan kecerdasan visual-spasial, seperti penelitian yang dilakukan oleh Ayu Dwi Lestari Oktavia tentang media buku bantal untuk meningkatkan kecerdasan visual-spasial anak di Taman Kanak-Kanak Sandhy Putra Telkom menyimpulkan bahwa media buku bantal dapat meningkatkan kecerdasan visual-spasial anak kelompok B1 di TK Sandhy Putra Telkom[20]. Selanjutnya penelitian yang dilakukan oleh Anggi Sulastri tentang bahan kolase untuk meningkatkan kecerdasan visual-spasial anak di TK Bina Anaprasa Kencana Bandar Khalifah menyimpulkan bahwa bahan kolase dapat meningkatkan kecerdasan visual-spasial anak[21].

Berdasarkan temuan penelitian sebelumnya yang telah dikemukakan di atas, baik temuan pada penelitian ini menyatakan bahwa media pembelajaran konstruktif sangat baik untuk mengembangkan kecerdasan visual-spasial anak usia 5-6 tahun yaitu melalui kegiatan bermain menggunakan objek untuk menciptakan suatu bentuk, yang dalam temuan peneliti terdahulu menunjukan bahwa media pembelajaran konstruktif dengan bermain geometri dan proyek dekorasi dapat meningkatkan kecerdasan visualspasial anak usia dini serta melalui kegiatan bermain playdough dapat meningkatkan kreativitas anak dalam mengembangkan imajinasinya untuk menciptakan bentukbentuk baru. Sedangkan pada temuan penelitian ini menggunakan media pembelajaran konstruktif melalui bermain menggunakan media playdough sehingga anak dapat dengan mudah menciptakan suatu bentuk dari imajinasinya. Maka temuan dalam penelitian ini dan temuan pada penelitian-penelitian terdahulu menunjukkan bahwa penggunaan media dalam pembelajaran sangat tepat digunakan sebagai sarana untuk menstimulasi perkembangan anak serta menunjukkan bahwa penggunaan media konstruktif dalam upaya meningkatkan kecedasan visual-spasial anak usia dini sangat tepat untuk digunakan sebagai salah satu sarana media pembelajaran anak usia 5-6 tahun.

\section{KESIMPULAN}

Permainan Playdough ini bisa menjadi alternatif guru dan orangtua dalam mengisi proses pembejaran pada masa pandemic covid-19. Bermaian playdough mampu meningkatkan perkembangan kecerdasan visual spasial anak usia dini pada masa pandemic covid-19. Home visit bisa menjadi alternatif untuk pendidik PAUD bisa menjalankan proses pembelajaran di rumah peserta didik. Berdasarkan hasil dan pembahasan yang telah dikemukakan maka dapat diambil kesimpulan bahwa bermain melalui media playdough dapat mengembangkan kecerdasan visual-spasial anak usia 56 tahun di PAUD Baitul Qur'an Kecematan Ranomeeto Kabupaten Konawe Selatan pada tiga indikator kecerdasan visual-spasial yaitu indikator koordinasi mata dan motorik dalam membuat berbagai bentuk sebanyak 80\%, indikator yang kedua yaitu kemantapan persepsi anak dalam mengenal macam-macam warna dan ragam bentuk sebanyak $90 \%$ dan indikator terakhir yang yaitu diskriminasi visual anak dalam membedakan berbagi bentuk hasil karya anak serta dapat membedakan ukuran suatu bentuk sebanyak $80 \%$. 


\section{PENGHARGAAN}

Terima kasih penulis ucapkan kepada kepala sekolah dan para guru yang di PAUD Baitul Qur'an Kecamatan Ranomeeto Kabupaten Konawe Selatan yang telah meluangkan waktunya untuk mengisi instrument penelitian ini dan semua pihak yang telah membantu pelaksanaan penelitian dan penulisan artikel ini. Tidak lupa ucapan terima kasih kepada editor dan reviewer Jurnal Murhum yang sudah memberikan kesempatan sehingga jurnal bisa untuk diterbitkan

\section{REFERENSI}

[1] L. Anhusadar, "Persepsi Mahasiswa PIAUD terhadap Kuliah Online di Masa Pandemi Covid 19," KINDERGARTEN J. Islam. Early Child. Educ., vol. 3, no. 1, p. 44, Apr. 2020.

[2] L. Hewi and L. Asnawati, "Strategi Pendidik Anak Usia Dini Era Covid-19 dalam Menumbuhkan Kemampuan Berfikir Logis," J. Obs. J. Pendidik. Anak Usia Dini, vol. 5, no. 1, p. 158, May 2020.

[3] N. Nurdin and L. Anhusadar, "Efektivitas Pembelajaran Online Pendidik PAUD di Tengah Pandemi Covid 19," J. Obs. J. Pendidik. Anak Usia Dini, vol. 5, no. 1, p. 686, Aug. 2020.

[4] K. Maryani, "Penilaian dan Pelaporan Perkembangan Anak Saat Pembelajaran di Rumah di Masa Pendemi Covid-19," Murhum J. Pendidik. Anak Usia Dini, vol. 1, no. 1, pp. 41-52, 2020.

[5] E. KOMALASARI, "Layanan Home Visit Pendidikan Anak Usia Dini Bagi Anak Kurang Sejahtera," Ta'dib, vol. 18, no. 1, p. 76, Oct. 2016.

[6] L. Anhusadar, "Kreativitas Pendidik di Lembaga PAUD," Al-Ta'dib, vol. 9, no. 1, pp. 76-93, 2016.

[7] A. Yus, Model pendidikan anak usia dini. Kencana, 2011.

[8] L. ROSIDAH, "Peningkatan Kecerdasan Visual Spasial Anak Usia Dini Melalui Permainan Maze," J. Pendidik. usia Dini, vol. 8, no. 2, pp. 281-290, 2014.

[9] J. Marpaung, "Pengaruh Pola Asuh Terhadap Kecerdasan Majemuk Anak," KOPASTA J. Progr. Stud. Bimbing. Konseling, vol. 4, no. 1, pp. 7-15, Dec. 2017.

[10] L. Hewi and S. Surpida, "Permainan Dadu pada Pengembangan Perilaku Prososial Anak di RA An-Nur Kota Kendari," JECED J. Early Child. Educ. Dev., vol. 1, no. 2, pp. 115-128, Dec. 2019.

[11] J. M. Asmani, "Panduan Praktis Manajemen Mutu Guru PAUD," Yogyakarta Diva, 2015.

[12] Y. N. Jatmika, Ragam aktivitas harian untuk playgroup. DIVA Press, 2012.

[13] N. Hanifah, Memahami penelitian tindakan kelas: teori dan aplikasinya. UPI Press, 2014.

[14] D. R. H. W. Sanjaya, Penelitian tindakan kelas. Prenada Media, 2016.

[15] S. Arikunto, Penelitian Tindakan Kelas. Jakarta: Bumi Aksara, 2009.

[16] N. Purwanto, "Prinsip-prinsip dan Teknik Evaluasi Pembelajaran," Bandung: Remaja Rosdakarya, 2010.

[17] Anas Sudijono, Pengantar Statistik Pendidikan. Jakarta: PT Raja. Grafindo Persada, 2010.

[18] Sira Difatiguna, "Pengaruh Aktivitas Bermain Menggunakan Playdough Terhadap Kemampuan Motorik Halus Pada Anak," 2015.

[19] C. E. P. Fransisca Anggraeni Suriantoso, Ni Made Ayu Suryaningsih, "Meningkatkan 
kemampuan motorik halus melalui permainan playdough pada anak kelompok bermain di paud tegaljaya," Pendidik. Univ. Dhyana Pura, vol. 1, no. 1, 2016.

[20] E. Jatiningsih, "Penggunaan Permainan Playdough Untuk Meningkatkan Kemampuan Mengenal Angka 1-10 Pada Anak Usia Dini 3-4 Tahun di TK Bahrul Ulun Mopuya," no. 1, pp. 1-4, 2020.

[21] A. Susantri, Upaya Mengembangkan Visual Spasial Anak Melalui Permainan Dengan Bahan Kolase Di Taman Kanak-Kanak Bina Anaprasa Kencana Bandar Khalifah Kecamatan Percut Sei Tuan Kabupaten Deli Serdang Tahun Ajaran 2016/2017, vol. 53, no. 9. 2019. 